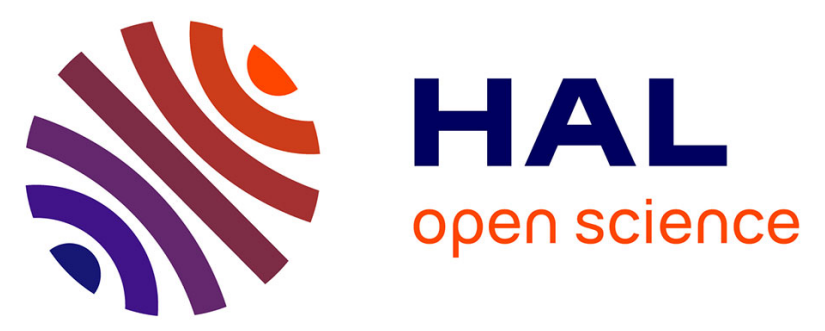

\title{
Social vulnerabilities and health conditions of arrestees in the Greater Paris area, France, in 2013: a multicentre cross-sectional study
}

Emilie Verdier, Céline Denis, Nacer Bourokba, Pierre Chauvin, Patrick

Chariot

\section{To cite this version:}

Emilie Verdier, Céline Denis, Nacer Bourokba, Pierre Chauvin, Patrick Chariot. Social vulnerabilities and health conditions of arrestees in the Greater Paris area, France, in 2013: a multicentre crosssectional study. International Journal of Legal Medicine, 2018, 132 (3), pp.897 - 905. 10.1007/s00414017-1727-y . hal-01912672

\section{HAL Id: hal-01912672 https://hal.sorbonne-universite.fr/hal-01912672}

Submitted on 5 Nov 2018

HAL is a multi-disciplinary open access archive for the deposit and dissemination of scientific research documents, whether they are published or not. The documents may come from teaching and research institutions in France or abroad, or from public or private research centers.
L'archive ouverte pluridisciplinaire HAL, est destinée au dépôt et à la diffusion de documents scientifiques de niveau recherche, publiés ou non, émanant des établissements d'enseignement et de recherche français ou étrangers, des laboratoires publics ou privés. 
Social vulnerabilities and health conditions of arrestees in the Greater Paris area, France, in 2013: a multicentre cross-sectional study

Emilie Verdier ${ }^{1}$, Céline Denis ${ }^{2}$, Nacer Bourokba ${ }^{3}$, Pierre Chauvin ${ }^{4}$, Patrick Chariot ${ }^{2,5}$

1 AP-HP, Hôpital Hôtel-Dieu, Department of Forensic Medicine, 75004 Paris, France

2 AP-HP, Hôpital Jean-Verdier, Department of Forensic Medicine, 93140 Bondy, France

3 AP-HP, Hôpital Raymond-Poincaré, Department of Forensic Medicine, 92160 Garches, France

4 Sorbonne Universités, UPMC Univ Paris 06, INSERM, Institut Pierre Louis d'Epidémiologie et de

Santé Publique, Department of Social Epidemiology, 75012 Paris, France

5 Sorbonne Paris Cité, Université Paris 13, Institut de recherche interdisciplinaire sur les enjeux

sociaux (IRIS), UMR 8156-997, UFR SMBH, 93000 Bobigny, France

Correspondence: Patrick Chariot, Service de médecine légale et de médecine sociale, hôpital JeanVerdier (AP-HP), 93140 Bondy, France. Phone: 33148026325. Fax: 33148026557 patrick.chariot@aphp.fr

Word count: 2610

2 tables, 1 figure

Int J Legal Med, accepted

Short title: Social vulnerabilities and health conditions of arrestees

Acknowledgements

None

Social vulnerabilities and health conditions of arrestees in the Greater Paris area, France, in 2013: a multicentre cross-sectional study

\section{Abstract}

Objective To describe the health and social conditions of arrestees, as compared to the general population.

Methods We studied a sample of 600 adult arrestees in 3 locations in the Greater Paris area, prospectively included (February-May 2013). A descriptive analysis has been performed, then prevalence was estimated using an indirect standardisation according to age, based on data from a population-based, representative survey in the same area.

Results Arrestees had a median age of $31 \mathrm{yrs}, 92 \%$ were males. As compared to the general population, arrestees had a lower level or education ( $8.6 \%$ vs. $7.6 \%, p<0.001)$, were more frequently unemployed $(42.0 \%$ vs. $11.9 \%, p<0.001)$ and in a difficult financial situation $(43 \%$ vs. $11 \%, p<0.001)$, and had less significant social support $(48.1 \%$ vs. $87.9 \%, p<0.001)$. They reported also more frequently a chronic health condition $(54 \%$ vs. $36 \%, p<0.001)$ and a limited health insurance coverage ( $36 \%$ vs. $15 \%, p<0.001$ ).

Conclusion Comparative analysis of male arrestees and males from the general population showed that the former had worse social and health conditions. These results argue for widespread medical interventions on all arrestees. Medical examination during detention could act as a gateway to health care and social support.

Key words: police custody; social condition; health status; arrestee; medical examination 


\section{Introduction}

Police custody is defined as detention in response to the suspicion of a crime or if the police have 'reasonable grounds' to suspect that someone aged 13 or older has committed an offense. According to French law, the person placed in custody may not be held for more than twenty-four hours [1]. The detention may be extended for a further period of up to twenty-four hours on the written authorisation of the district prosecutor. In rare cases defined by law (e.g. suspicion of terrorism attacks, drug dealing), the detention can last up to six days. The number of detainees held in police custody in France is now estimated to be approximately 700,000 per year [2]. French law states that any person placed in police custody may, at their request, be examined by a doctor. The medical examination can also be performed at the request of a police officer or the individual's family. The doctor states the fitness of the person to be held further in custody and notes any relevant findings [1]. Although there are no official statistics, it has been estimated that $50-75 \%$ police custody detainees have a medical examination [3].

Health issues among arrestees are a worldwide concern for which no international policies have been established [4-7]. Medical data regarding arrestees are scarce across countries [5,6,8,9]. International standards recommend that a detainee's right to medical care be equivalent to that available to the general community $[6,10]$. Social vulnerabilities can have both short- and long-term health consequences [11]. Mental health, somatic and addictive disorders have already been studied among arrestees [8,12-15]. A comparison of demographic and social data between arrestees and the general population in Amsterdam showed that most detainees were single young males, with a lower level of education and often unemployed [6]. Social characteristics of detainees in police custody have not been studied in most countries, including France. In the present article, we studied the demographic characteristics, medical conditions, and social situation of arrestees. Our aim was to describe their health and social characteristics, as compared to the general population of the same region.

\section{Methods}

\section{Design and setting}

We conducted a cross-sectional study based on a prospective sample of all the arrestees examined, at their own request or at the police's request, by four trained forensic physicians between February and May 2013. These physicians worked in 3 départements of the Greater Paris area: Paris city (a département by itself), Seine-Saint-Denis and Hauts-de-Seine (both in Paris close suburb: the former being the poorest of the Greater Paris area and the latter one of the wealthiest in France but with huge social disparities). These 3 départements are counting 5.4 million inhabitants, i.e. $77 \%$ of the total Greater Paris population.

A total of 200 arrestees were interviewed per location, between February and May 2013. The questions were asked by four trained forensic physicians.

\section{Study population}

We included all the consecutive arrestees aged 18 and over, who spoke French and gave their oral consent to participate. Since this research does not fall into the category of biomedical research as defined by the French law and did not collect any nominative date, a written consent was not required [16]. Arrestees with insufficient knowledge of French for the medical interview, in a delusional state, with aggressive or threatening behaviours, with abnormal vital signs and drug bodypackers were excluded from the survey. The medical examination was performed and the survey questions were asked where they could not be seen or overheard by any third party to preserve the arrestee's dignity and the physician's duty of confidentiality. The project has been reviewed and approved by the Institutional Review Board (IRB 00001072) of Ile-de-France II (Paris, France).

Data in the general population came from a population-based, random sample of 3,000 French speaking adults interviewed in 2010 in the framework of the SIRS cohort survey. This survey and its sample design have been described elsewhere (SIRS). The comparison between the arrestees and the individuals from the SIRS study was based on 18 questions in common in the questionnaires used in the SIRS survey and in the present project.

\section{Variables}


The questionnaire was made of 34 questions, covering the following dimensions: (i) Demographics (gender, age, nationality, marital situation); (ii) Socioeconomic status (level of education, employment situation, perceived financial situation); (iii) Other social characteristics (living in social housing, social support, self-perception of loneliness, access to health care), as asked in the SIRS questionnaire; (iv) Health conditions: Minimum European Health Module $[17,18]$, as well as a group a questions about medical history of somatic and mental health disorders, feeling of own medical situation, medical treatments, and addictive behaviours, using a DSM IV-based evaluation. This group of questions was based on the recommendations of a national consensus conference on health issues in police custody [19-22].

Social support was evaluated by the following question: "In case of need, could you count on someone, either members of your household or family, friends, colleagues or neighbours, to: help you in everyday life or give you a hand? (Yes/No); provide financial or material support (e.g., food, clothing)? (Yes/No); provide moral or emotional support? (Yes/No)?". The three items were combined to create a single score from 0 (absent social support) to 3 (excellent social support).

The questionnaire also included specific data on detainees' own experiences of police custody (whether or not it was their first time in custody), and reported assaults or observed injuries. Detainees' health insurance coverage was rated as full, partial, limited and absent.

\section{Statistical Analyses}

Analyses were performed with SPSS software (IBM SPSS Statistics for Windows, Version 20.0. Armonk, NY, USA). Tests of significance included chi-square tests and ANOVA, as appropriate. The differences were considered significant for $p$ values below 0.05 . First, data from the three centres were compared to each other. Then distributions of arrestees' characteristics were standardized according to the age distribution of the male population in the SIRS survey in order to compare both populations.

\section{Results}

Our sample consisted of 797 patients (M/F, 767/30; 96\%/4\%). Figure 1 shows a flow chart of inclusion. Inclusion rates were $84 \%$ in Paris, $82 \%$ in the Hauts-de-Seine and $84 \%$ in Seine-Saint-Denis. Exclusion from the survey was related to acute mental health disorders in 35 arrestees (4\%).

\section{Descriptive characteristics of arrestees}

Table 1 presents the health and social characteristics of arrestees.

\section{Demographics and social situations}

Males accounted for a high proportion of arrestees (555/600, 92\%). Median age was 31, with significant differences across the three départements surveyed. A total of 455 (76\%) were French citizens, 209 (35\%) were singles without romantic relationship, and 476 (79\%) had been previously detained in police custody. Compared analysis across the three départements showed that arrestees in Paris were older and more often non-French citizens, with a lower educational level and/or a difficult financial situation. They felt also lonelier and had a lower social support. Social housing was more commonly reported by arrestees from the suburban départements than those from Paris city. Unemployment rates were similar in the three départements.

\section{Health conditions}

One third of arrestees $(179 / 600,30 \%)$ reported one $(132 / 600,22 \%)$ or more $(47 / 600,8 \%)$ somatic disorders. The most frequent medical conditions reported were asthma (10\%), arterial hypertension (6\%), and diabetes (5\%). Mental health disorders were reported by 130 of 600 arrestees (22\%), of whom $74(57 \%)$ received ongoing care. A total of 91 of 600 arrestees (15\%) received psychoactive treatment. One third of arrestees (33\%) had a chronic health condition, $29 \%$ considered to be limited or severely limited in everyday activities, and $33 \%$ rated their overall health as average, bad or very bad.

Seventy percent of arrestees reported to be registered with a general practitioner (which is required in order to benefit from the best coverage of health care expenditures by the French health 
insurance) and only $32 \%$ had full health insurance coverage. Fourteen percent had no access to health care services.

Compared analysis across the three départements showed that higher proportions of arrestees in Paris reported chronic health conditions or mental health disorders, rated their health as bad and had limited access to health care.

\section{Addictive behaviours}

A total of $74 / 600$ individuals (12\%) reported daily alcohol consumption, of which $44(7 \%)$ reported to drink at least 5 glasses daily. Furthermore, 426/600 individuals (71\%) reported daily tobacco consumption, including 301 (50\%) who smoked 10 cigarettes or more. Half of the arrestees (259/600) reported cannabis consumption in the last week, including 207 (34\%) who reported daily smoking. Cocaine or crack use was reported by 49 of 600 arrestees (8\%) including 18 (3\%) who reported a daily consumption, heroin use by 10 of $600(2 \%)$ and an opioid replacement therapy by $40(7 \%)$ individuals. Higher proportions of arrestees in Paris reported daily alcohol use, cocaine/crack or heroin use.

\section{Comparative characteristics of male arrestees and males from the general population}

Table 2 shows the age-standardized comparison of social and demographic characteristics of male arrestees and males from the general population [23]. The mean ages of male arrestees and males in the general population were $30.0 \mathrm{yrs}$ and $45.5 \mathrm{yrs}$, respectively.

\section{Demographics and social situations}

Lower proportions of arrestees were French citizens, had a high social support, a high level of education and/or unlimited access to health care services ( $69 \%$ vs. $86 \%, 48 \%$ vs. $88 \%, 26 \%$ vs. $56 \%$ and $48 \%$ vs. $88 \%$, respectively). Arrestees were also significantly more often single, unemployed, in a difficult financial situation and living in social housing ( $32 \%$ vs. $21 \%, 42 \%$ vs. $12 \%, 43 \%$ vs. $11 \%$, and $36 \%$ vs. $23 \%$, respectively).

\section{Health conditions}

The reported prevalence of chronic health conditions and limitations in everyday activities were significantly higher in male arrestees than in the general male population ( $54 \%$ vs. $36 \%$ and $48 \%$ vs. $18 \%$, respectively). Accordingly, arrestees reported more frequently a deteriorated (average, bad, very bad) perceived health than the male general population ( $48 \%$ vs. $21 \%$ ).

\section{Discussion}

In this study, we presented the demographic characteristics, social situations and health conditions of arrestees in the Greater Paris area. Arrestees were predominantly young males. One third perceived their health as deteriorated, $30 \%$ of them reported somatic disorders and $22 \%$ reported mental health disorders. As compared to the general population, higher proportions of arrestees had a low social support, were currently unemployed and in a difficult financial situation. These results are consistent with a study comparing arrestees and the general population in Amsterdam which found also that arrestees had a lower level of education and a higher rate of unemployment, and were more often single [6].

Only arrestees aged over 18 were included. In addition, the presented data related to examined individuals who had sufficient knowledge of French, which included most but not all detainees. These methodological options were related to the design of the SIRS survey, that was restricted to adult French-speaking individuals [23]. The proportions of individuals reporting chronic somatic disorders were higher in the present study (including in the centre in Seine-Saint-Denis) than in a previous local study among adult and adolescent arrestees in Seine-Saint-Denis, which showed $5 \%$ of arrestees with asthma, $2 \%$ with diabetes, $1 \%$ with epilepsy, and $2 \%$ with high blood pressure [8]. Arrestees in Paris reported a chronic health condition more often, possibly related to the older age of arrestees in Paris, but they also reported also more mental health disorders.

The finding of a worse perceived health status among arrestees than in the general population is in accordance with the Amsterdam study, which showed that arrestees were 1.6 times more likely to report a chronic health condition than the general population [6]. The proportions of arrestees 
registered with a general practitioner were similar in our study and among arrestees from Amsterdam in 2009 (71\% and 72\%, respectively) and lower than in the French general population in $2008(85 \%)[6,24]$.

The proportion of arrestees reporting mental health disorders in this study $(22 \%)$ is close to the $24 \%$ observed among arrestees in London [9]. Exclusion of arrestees with delusional states, aggressiveness or threatening behaviours possibly lowered this proportion. Of arrestees reporting mental health issues in our study, $57 \%$ received current mental health care, accounting for $13 \%$ of all arrestees included in the study. In two previous studies among adult and adolescent arrestees in Seine-Saint-Denis (one of the departments presently studied) a history of mental health disorders was reported by only $5 \%$ and $6 \%$ of arrestees, respectively, of whom nearly a half had ongoing care but those proportions cannot be easily compared since both studies had included much younger people $[3,8]$. Few comparable data are available from other countries. In Victoria State, Australia, a survey conducted with 614 arrestees showed that $16 \%$ were currently receiving mental health care [13]. Screening for mental illness among a sample of arrestees in Amsterdam showed that $40 \%$ were screened positive for a serious mental condition [25]. In Victoria State and Amsterdam, previous contacts with the public mental health system were identified in $55 \%$ and $26 \%$ of arrestees, respectively $[13,26]$.

Addictive behaviours were reported by most arrestees. Daily tobacco use and regular cannabis use accounted for $71 \%$ and $43 \%$ of arrestees, respectively, which are markedly higher proportions than in the French general population aged over 18 (29\% and 3\%, respectively) as well as in the male population over 18 (33\% and 5\%) [27]. The proportions of tobacco smokers were similar to previous studies among French arrestees and in Amsterdam and London police stations, that reported $62-77 \%$ of arrestees smoking tobacco $[3,6,8,9,15]$. The reported proportion of cannabis smokers was high, as compared with the $20-30 \%$ published previously $[6,8,9,15]$. The limitation of this study to adults could partly explain the observed difference with a previous study conducted among adults and adolescents arrested in Seine-Saint-Denis [8]. On the opposite, the prevalence of daily alcohol consumption observed in our study $(12 \%)$ is close to those observed previously in arrestees in SeineSaint-Denis [8] and in the French adult general population (10\%) [27]. Compared analysis across centres showed higher proportions of cocaine/crack and heroin among arrestees detained in Paris city, which is in accordance with the unique position of Paris in French illicit drug market [28].

This study has several limitations. First, examined arrestees only included those who were examined at their request or at the request of their family or of the police. That examined arrestees were in a worse health condition than those who were not examined is a reasonable hypothesis. This might partly explain the differences observed with data from the SIRS cohort survey. In France, there are no official statistics on the frequency of medical examinations in police custody. In the Greater Paris area, the proportion of examined arrestees is estimated to be $50 \%-75 \%$. In Seine-Saint-Denis, the proportion of detainees who had medical examinations is particularly high and was estimated to be approximately $75 \%$ in 2011 [3]. Such a high proportion could be explained by the availability of forensic physicians in that area. Second, the medical histories were mainly based on detainees' selfreports. However, the reliability of the data gathered from arrestees during a medical examination has been previously demonstrated [29]. Third, international comparisons are made difficult by different legal regulations, particularly because, in some countries, access to a medical examination depends on an assessment made by the police [14,30,31].

In conclusion, individuals detained in police stations are commonly socially disadvantaged and isolated, with high prevalence of chronic or mental health problems and lower access to health care. These results argue for widespread medical interventions on all arrestees. Moreover, brief interventions in addictive behaviours, mental health and nutrition have been shown feasible among arrestees in most cases $[15,32]$ when they take into account individuals' social situation and living conditions. Our findings plea for implementing such interventions that could be incorporated into the public health missions of physicians caring for patients in police custody.

\section{Conflicts of interest: None}

Ethical statement: The project has been reviewed and approved by the Institutional Review Board (IRB 00001072) of Ile-de-France II (Paris, France). 


\section{References}

1. French code of criminal procedure (2017) Articles 62 to 64. Legifrance.gouv.fr. Available at: http://www.legifrance.gouv.fr/affichCode.do?cidTexte=LEGITEXT000006071154\&dateTexte=2 0140302 (4 September 2017, date last accessed).

2. Le Monde (2011). Baisse du nombre des gardes à vue en 2010 (Fewer detentions in police custody in 2010). Le Monde, January 25, 2011. Available at:

www.lemonde.fr/societe/article/2011/01/25/baisse-du-nombre-des-gardes-a-vue-en2010_1470197_3224.html (4 September 2017, date last accessed).

3. Gilard-Pioc S, Dang-Hauter C, Denis C, Boraud C, Chariot P (2013) Detainees in police custody in Seine-Saint-Denis (France): Medical data and high-risk situations, a descriptive study. Presse Med 42:293-299. doi: 10.1016/j.lpm.2013.01.055

4. Lancet (1993) Three-faced practice: doctors and police custody [Editorial]. Lancet 341:1245-1247.

5. Heide S, Stiller D, Lessig R, Lautenschläger C, Birkholz M, Früchtnicht W (2012) Medical examination of fitness for police custody in two large German towns. Int J Legal Med 26:27-35. doi: 10.1007/s00414-011-0557-6

6. Ceelen M, Dorn T, Buster M, Stirbu I, Donker G, Das K (2012) Health-care issues and health-care use among detainees in police custody. J Forensic Leg Med 19:324-331. doi: 10.1016/j.jflm.2012.02.012

7. Payne-James JJ, Anderson WR, Green PG, Johnston A (2009) Provision of forensic medical services to police custody suites in England and Wales: current practice. J Forensic Legal Med 16:189195. doi: 10.1016/j.jflm.2008.09.002

8. Chariot $P$, Beaufrère $A$, Denis $C$, Dang $C$, Vincent $R$, Boraud $C$ (2014a) Detainees in police custody in the Paris, France area: medical data and high-risk situations (a prospective study over 1 year). Int J Legal Med 128:853-860. doi: 10.1007/s00414-014-0990-4.

9. Payne-James JJ, Green PG, Green N, McLachlan GM, Munro MH, Moore TC (2010) Healthcare issues of detainees in police custody in London, UK. J Forensic Legal Med 17:11-17. doi: 10.1016/j.jflm.2007.10.011

10. Council of Europe committee of ministers (2006) Recommendation rec(2006)2 of the committee of ministers to member states on the European prison rules. Available at: https://wcd.coe.int/ViewDoc.jsp?id=955747 (4 September 2017, date last accessed).

11. Grabovschi C, Loignon C, Fortin M (2013) Mapping the concept of vulnerability related to health care disparities: a scoping review. BMC Health Services Research 13:94.

12. Gregory M (2007) Characteristics of drug misusers in custody and their perceptions of medical care. J Forensic Legal Med 14:209-212.

13. Ogloff J, Warren L, Tye C, Blaher F, Thomas S (2011) Psychiatric symptoms and histories among people detained in police cells. Soc Psychiatry Psychiatr Epidemiol 46:871-880. doi: 10.1007/s00127-010-0256-5

14. McKinnon IG, Grubin D (2013) Health screening of people in police custody - Evaluation of current police screening procedures in London, UK. Eur J Public Health 23:399-405. doi: 10.1093/eurpub/cks027

15. Chariot $P$, Lepresle A, Lefèvre $T$, Boraud $C$, Barthès $A$, Tedlaouti $M$ (2014b) Alcohol and substance screening and brief intervention for detainees kept in police custody. A feasibility study. Drug Alcohol Depend 134:235-241. doi: 10.1016/j.drugalcdep.2013.10.006

16. Claudot F, Alla F, Fresson J, Calvez T, Coudane H, Bonaïti-Pellié C (2009) Ethics and observational studies in medical research: various rules in a common framework. Int J Epidemiol $38: 1104$ 1108. doi: $10.1093 /$ ije/dyp164

17. Cox B, van Oyen H, Cambois E, Jagger C, Le Roy S, Robine JM, Romieu I (2009) The reliability of the Minimum European Health Module. Int J Public Health 2009;54:55-60.

18. European Health Expectancy Monitoring Unit (2010) The Minimum European Health Module. Available at: http://www.eurohex.eu/pdf/Reports_2010/2010TR4.6_Health\%20Module.pdf. (4 September 2017, date last accessed).

19. Agence nationale d'accréditation et d'évaluation en santé (French National Authority for Health) (2005) Intervention du médecin auprès de personnes en garde à vue (Medical intervention in police custody). Available at: http://www.has- 
sante.fr/portail/upload/docs/application/pdf/Garde_vue_long.pdf. (4 September 2017, date last accessed).

20. Chariot P, Martel P, Penneau M, Debout M (2008) Guidelines for doctors attending detainees in police custody. Int J Legal Med 122:73-76.

21. Briffa $H$, Lefèvre $T$, Boraud $C$, Chariot $P$ (2013) Intervention du médecin en garde à vue: proposition d'un certificat médical amélioré. Presse Med 42:e9-15. doi: 10.1016/j.lpm.2012.04.027

22. Chariot $P$, Briffa $H$, Lepresle A, Lefèvre T, Boraud C (2013) Fitness for detention in police custody: a practical proposal for improving the format of medical opinion. J Forensic Legal Med 20:980985. doi: 10.1016/j.jflm.2013.07.006

23. SIRS: Santé, Inégalités et Ruptures Sociales (Health, Inequality and Social Disruption). France. Available at: http://www.programme-sirs.org/les-resultats/les-publications-scientifiques/. (4 September 2017, date last accessed).

24. Assurance Maladie (2009) Le médecin traitant, adopté par la majorité des Français, favorise la prévention, January 22 2009. Available at:

http://www.ameli.fr/fileadmin/user_upload/documents/Bilan_medecin_traitant_Vdef2.pdf. (4 September 2017, date last accessed).

25. Dorn T, Ceelen M, Buster M, Das K (2013) Screening for mental Illness among persons in Amsterdam police custody. Psychiatr Serv 64:1047-1050. doi: 10.1176/appi.ps.201200009

26. Buster M, Dorn T, Ceelen M, Das K (2014) Detainees in Amsterdam, a target population of the public mental health system? J Forensic Legal Med 25:55-59. doi: 10.1016/j.jflm.2014.04.015

27. Observatoire français des drogues et des toxicomanies (2015) Drugs, Key data. 6th edn, 2015. Available at: http://www.ofdt.fr/BDD/publications/docs/dcc2015.pdf. (4 September 2017, date last accessed).

28. Cadet-Taïrou A, Gandilhon M, Lahaie E, Martinez M, Dambele S, Saïd S (2013) Marchés, substances, usagers : les tendances récentes (2011-2012). (Markets, substances, users : recent trends). Tendances 86 :1-8. http://www.ofdt.fr/BDD/publications/docs/eftxact7.pdf. (4 September 2017, date last accessed).

29. Stark MM, Norfolk G, Rogers DJ, Payne-James JJ (2002) The validity of self-reported substance misuse among detainees in police custody. J Clin Forensic Med 9:25-26.

30. McKinnon I, Srivastava S, Kaler G, Grubin D (2013) Screening for psychiatric morbidity in police custody: results from the HELP-PC project. The Psychiatrist 37:389-394.

31. Heide S, Chariot P, Green P, Fabian J, Payne-James JJ (2017) Healthcare and forensic medical aspects of police detainees, suspects and complainants in Europe. J Forensic Legal Med in press. http://dx.doi.org/10.1016/j.jflm.2016.01.022.

32. Lefèvre T, Denis C, Marchand C, Vidal C, Gagnayre R, Chariot P (2017) Multiple brief interventions in police custody: The MuBIC randomized controlled study for primary prevention in police custody. Protocol and preliminary results of a feasibility study in the Paris metropolitan area, France. J Forensic Legal Med, in press. http://dx.doi.org/10.1016/j.jflm.2016.05.019. 


\begin{tabular}{|c|c|c|c|c|c|}
\hline & $\begin{array}{l}\text { All detainees } \\
\begin{array}{c}\mathrm{N}=600 \\
(\%)\end{array}\end{array}$ & $\begin{array}{c}\text { Paris } \\
\mathrm{N}=200 \\
(\%)\end{array}$ & $\begin{array}{l}\text { Hauts- } \\
\text { de-Seine } \\
\mathrm{N}=200 \\
(\%)\end{array}$ & $\begin{array}{l}\text { Seine- } \\
\text { Saint-Denis } \\
\mathrm{N}=200 \\
(\%)\end{array}$ & $\chi^{2}, P$-value \\
\hline \multicolumn{6}{|l|}{ Demographics } \\
\hline Gender, M/F & $555 / 45(92.5 / 7.5)$ & $1 / 9$ & $94 / 6$ & $92.5 / 7.5$ & 0.523 \\
\hline Age, mean/median, yrs & $31 / 27$ & $34 / 33$ & $30 / 26$ & $28 / 25$ & $<0.001$ \\
\hline French / Non-French nationality & $455 / 45(75.8)$ & $67.5 / 32.5$ & $77.5 / 22.5$ & $82.5 / 17.5$ & 0.002 \\
\hline Marital situation & & & & & 0.677 \\
\hline $\begin{array}{l}\text { Single without romantic } \\
\text { relationship }\end{array}$ & $209(34.8)$ & 35.5 & 35.5 & 33.5 & \\
\hline Single with romantic & & & & & \\
\hline relationship & $130(21.7)$ & 19.0 & 19.5 & 26.5 & \\
\hline Couple who do not live together & $100(16.7)$ & 17.5 & 15.5 & 17 & \\
\hline Couple who live together & $156(26.0)$ & 27.5 & 27.5 & 23.0 & \\
\hline Missing data & $5(0.8)$ & 0 & 1.5 & 0 & \\
\hline \multicolumn{6}{|l|}{ Socioeconomic status } \\
\hline Level of education & & & & & $<0.001$ \\
\hline Lower education level & $25(4.2)$ & 7.0 & 3.5 & 2.0 & \\
\hline Middle school & $169(28.2)$ & 31.5 & 36.0 & 17.0 & \\
\hline High school & $306(51.0)$ & 39.0 & 46.0 & 68.0 & \\
\hline University & $100(16.7)$ & 22.5 & 14.5 & 13.0 & \\
\hline Highest degree obtained & & & & & 0.001 \\
\hline No degree & $181(30.2)$ & 33.5 & 29.5 & 27.5 & \\
\hline Certificate of general education & $74(12.3)$ & 8.0 & 9.5 & 19.5 & \\
\hline $\begin{array}{l}\text { Certificate of professional } \\
\text { competence or vocational } \\
\text { baccalaureate }\end{array}$ & $217(36.2)$ & 31.5 & 42.0 & 35.0 & \\
\hline $\begin{array}{l}\text { General or technical } \\
\text { baccalaureate }\end{array}$ & $40(6.7)$ & 9.5 & 4.5 & 6.0 & \\
\hline Higher learning & $84(14.0)$ & 17.5 & 14.5 & 10.0 & \\
\hline Missing data & $4(0.7)$ & 0.0 & 0.0 & 2.0 & \\
\hline Employment situation & & & & & $<0.001$ \\
\hline Employed & $270(45.0)$ & 43.0 & 47.0 & 45.0 & \\
\hline Students and trainees & $48(8.0)$ & 7.0 & 5.5 & 11.5 & \\
\hline Currently unemployed & $180(30.0)$ & 42.0 & 35.0 & 13.0 & \\
\hline Retired & $8(1.3)$ & 2.5 & 0.5 & 1.0 & \\
\hline Inactive & $94(15.7)$ & 5.5 & 12.0 & 29.5 & \\
\hline Perceived financial situation & & & & & $<0.001$ \\
\hline Good & $226(37.7)$ & 24.5 & 38.5 & 50.0 & \\
\hline Careful with their money & $151(25.2)$ & 30.5 & 24.0 & 21.0 & \\
\hline Difficult & $223(37.2)$ & 45.0 & 37.5 & 29.0 & \\
\hline \multicolumn{6}{|l|}{ Other social characteristics } \\
\hline Living in social housing & $263(43.8)$ & 33.0 & 54.0 & 44.5 & $<0.001$ \\
\hline Score of social support & & & & & 0.001 \\
\hline 0 (no support) & 87 (14.5) & 13.5 & 14.5 & 16.0 & \\
\hline 1 (low support) & $61(10.2)$ & 13.5 & 9.0 & 8.0 & \\
\hline 2 (medium support) & $100(16.7)$ & 23.5 & 15.0 & 11.5 & \\
\hline 3 (high support) & $351(58.5)$ & 50.0 & 61.0 & 64.5 & \\
\hline
\end{tabular}


Self-perception of loneliness

Very lonely

86 (14.3)

19.5

15.5

0.011

Rather lonely or rather

surrounded

416 (69.3)

63.5

67.0

8.0

$96(16.0)$

16.5

17.5

77.5

Very surrounded

$2(0.3)$

0.5

0.0

14.0

Health insurance coverage

191 (31.8)

25.0

36.0

0.021

Full

$114(19.0)$

24.0

13.0

Partial

$211(35.2)$

33.5

39.0

Limited

84 (14.0)

17.5

12.0

33.0

No

Registrered with GP

$423(70.5)$

70.5

71.5

12.5

69.5

0.908

\section{Health conditions}

Mini European Health Module

Chronic health condition

197 (32.8)

$172(28.7)$

50.0

25.0

23.5

$<0.001$

Functional limitations ${ }^{\text {a }}$

193 (32.2)

40.0

32.0

14.0

$<0.001$

Deteriorated perceived health ${ }^{\mathrm{b}}$

52.0

27.0

8.5

$<0.001$

Medical history of somatic and mental health disorders

No health disorder

421 (70.2)

56.0

72.0

82.5

$<0.001$

One or several health disorders

$179(29.8)$

44.0

28.0

17.5

Asthma

$61(10.2)$

13.5

11.0

6.0

0.041

Hypertension

$35(5.8)$

8.5

5.0

4.0

0.131

Diabetes mellitus

$31(5.2)$

6.5

3.5

0.386

Epilepsy

22 (3.7)

5.5

5.5

0.099

Mental health disorder

$130(21.7)$

34.0

4.0

1.5

$<0.001$

\section{Treatments}

Psychoactive treatment

$91(15.2)$

23.5

20.0

11.0

15.5

6.5

$<0.001$

$40(6.7)$

15.5

3.5

1.5

$<0.001$

Any other treatment

94 (15.7)

12.5

19.0

0.201

Addictive behaviours

Alcohol use ${ }^{c}$

74 (12.3)

21.0

7.5

7.0

$<0.001$

Tobacco use ${ }^{c}$

426 (71.0)

75.5

66.5

70.0

0.140

Cannabis use $^{d}$

$259(43.2)$

47.5

37.5

44.5

0.117

Cocaine/ crack use ${ }^{d}$

$49(8.2)$

16.0

4.5

$<0.001$

Heroin use ${ }^{d}$

10 (1.7)

3.5

1.0

4.0

0.043

\section{History of detention}

First Custody

$124(20.7)$

21.5

19.5

21.0

0.759
a: Severe or not
b: Average, bad or very bad
c: Daily consumption
$\mathrm{d}$ : Any consumption during the last week 
Table 2. Age-standardized comparison of social characteristics between male arrestees and the male general population in the Greater Paris area.

$\begin{array}{cc}\text { Arrestees } & \text { General population } \\ n=555(\%) & n=1411(\%)\end{array}$

Demographics

Nationality

$n=1411(\%)$

French

Non French

Marital situation

Single without romantic relationship

Single with romantic relationship

Couple who do not live together

Couple who live together

Missing data

Socioeconomic status

Level of education

Lower education level

8.6

27.5

37.9

High school

26.0

Highest degree obtained

69.0

31.0

32.5

17.6

13.2

0.2

0.6

31.0

7.0

30.9

6.8

23.7

0.6

48.8

2.5

27.6

6.7

14.5

32.3

25.1

42.6

Difficult financial situation

Other social characteristics

Score of social support

0 (no support)

19.0

11.4

21.0

1 (low support)

Perceived financial situation
$<0.001$

86.0

14.0

21.5

11.5

6.2

60.8

0.0

$<0.001$

$<0.001$

7.6

14.5

21.5

56.4

9.5

9.7

19.2

9.3

52.4

0.0

60.6

9.4

9.3

18.1

2.7

60.3

28.1

11.2

$<0.001$

7

.

3

0.0

$<0.001$

4

.7

$<0.001$
1.1

2 (medium support)

2.5

8.4 
3 (high support)

Self-perception of Ioneliness

Very lonely

Rather lonely or rather surrounded

Very surrounded

Missing data

Health insurance coverage

Full

Partial

Limited

No

\section{Health conditions}

Mini European Health Module Chronic health condition

Functional limitation ${ }^{b}$

Deteriorated perceived health ${ }^{c}$
48.2

88.0

18.1

66.8

14.6

0.4

48.1

18.9

36.1

10.2

54.4

36.3

$<0.001$

47.6

17.8

$<0.001$

48.3

20.8
$<0.001$

87.9

14.9

0.2

7.1

31.0

.0

8

.2
$<0.001$
a: Age-adjusted data
b: Severe limitation or limitation
c: Average, bad or very bad opinion 